\section{Strongyloidiasis in ex-Far East prisoners of war}

Infestations with the nematode worm Strongyloides stercoralis are common in the tropics, and may persist for many years. Although often asymptomatic, infestations may be associated with diarrhoea or skin lesions. Our experience suggests that this eruption is quite common among ex-Far East prisoners of war, and we have therefore investigated and treated a group of these patients with encouraging results.

\section{Patients, methods, and results}

From April 1974 to December 1975100 male British ex-Far East prisoners of war aged 50 to 71 years were consecutively admitted to the tropical diseases unit of Sefton General Hospital for tropical disease screening under our care, generally for pension assessment purposes. The men had been imprisoned by the Japanese in the Far East during 1942-1945. All had enjoyed good health before imprisonment, and since repatriation in 1945 none had returned to the tropics. Of this group 11 volunteered histories of typical strongyloid rash dating back to the war, and in some the eruption was seen in the ward. Strongyloid rash is an itching, serpiginous, urticarial eruption that resembles cutaneous larva migrans caused by non-human hookworms. Strongyloid lesions appear and disappear in a few hours or days, whereas the lesions produced by non-human hookworms may persist for months (see figure).

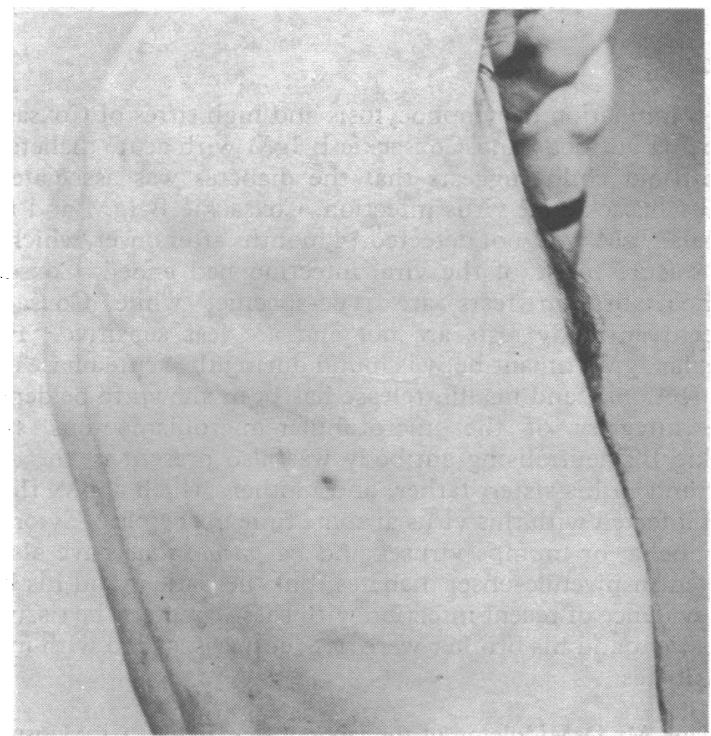

Typical strongyloid rash showing serpiginous, urticarial eruptions.

Investigation of these 11 patients included stool microscopy, and culture for larvae using charcoal (three specimens), blood eosinophil count, and complement fixation test (CFT) using antigen prepared from Ascaris lumbricoides. They were then treated with thiabendazole $25 \mathrm{mg} / \mathrm{kg}$ twice daily for three days. Because many patients came from distant parts of Britain we assessed the effectiveness of treatment by postal questionnaires sent from three to 15 months after treatment in which they were asked if the rash had disappeared completely without recurrence ("cured"), was reduced in severity ("improved"), or had continued as before ("unchanged").

Seven of the 11 patients with strongyloid rash showed an eosinophilia over $5 \%$ and results of CFT were positive in five patients. Larvae were found in the stools of only two patients. Three patients failed to reply to the questionnaire. One patient died three weeks after completing thiabendazole treatment; necropsy showed cirrhosis and a splenic artery aneurysm that had ruptured into the pancreas. The therapeutic response was "cured" in six of the remaining seven patients and "improved" in the other one. Side effects necessited neither interruption of treatment nor delay in discharge from hospital.

\section{Comment}

We think that the good response to thiabendazole confirms strongyloidiasis as the likely cause of the rash. Thiabendazole is the drug of first choice; side effects, though common, are usually mild, transient, and outweighed by the therapeutic efficacy. ${ }^{1}$ Because mebendazole is not well absorbed it is less toxic than thiabendazole, but has correspondingly less effect on the tissue stages of $S$ stercoralis.

Since many ex-Far East prisoners of war live in this country there may be many victims with unsuspected strangyloidiasis in the community; and with holiday travel to the tropics increasing, the incidence is likely to rise. We would recommend a therapeutic trial of thiabendazole in all patients who have been in the tropics and have a typical rash even though strongyloides larvae are not found. This should cure the symptoms and prevent the hyperinfective cycle. ${ }^{2}$ The latter may present as malabsorption, meningitis, or intestinal obstruction $^{3}$ and, if immunosuppressive drugs such as steroids are given, may be lethal. 4

1 Davis, A, Drug Treatment in Intestinal Helminthiasis. Geneva, World Health Organisation, 1973.

2 Brown, H W, and Perna, V P, fournal of the American Medical Association, 1958, 168, 1648.

3 Walker, A C, Blake, G, and Downing, D, Medical fournal of Australia, 1976, 1, 47.

- Adams, M, et al, British Medical fournal, 1973, 1, 264.

Liepman, M, fournal of the American Medical Association, 1975, 231, 387.

(Accepted 18 fanuary 1977)

Liverpool School of Tropical Medicine, Liverpool L3 5QA

GEOFFREY V GILL, MRCP, DTM\&H, house physician (present appointment: consultant physician, Nchanga Hospitals, POB63, Chingola, Zambia)

DION R BELL, FRCP, DTM\&H, consultant physician

H ALISTAIR REID, OBE, FRCP, consultant physician

\section{Laparoscopic sterilisation with Silastic-band technique}

Although laparoscopic tubal diathermy is a useful and widely used method of female sterilisation, it is nevertheless associated with a persistent, albeit low, incidence of inadvertent electrocautery burns of the bowel and abdominal wall. ${ }^{1}$ In an attempt to obviate this complication Yoon has developed a technique of applying Silastic bands to the uterine tubes, which is reported as being an effective and simple procedure. $^{2}$ We used the technique to sterilise 100 women in a general gynaecological unit, and report here the results.

\section{Method and results}

We used the method developed and described by Yoon. ${ }^{2} 3$ The laparoscope and Silastic-band applicator were inserted through separate abdominal wall puncture sites. One hundred consecutive patients requesting laparoscopic sterilisation were sterilised in this way and seen for follow-up two weeks afterwards. All the operations were successful in that Silastic bands were applied to both uterine tubes. In two patients the ring was initially applied to the mesosalpinx but this was recognised and another ring applied correctly. In three patients the grasp forceps was misapplied causing bleeding from the mesosalpinx, but the ring was subsequently reapplied over the tube and mesosalpinx, thus arresting further haemorrhage.

The only notable complication to date has been a high incidence of postoperative lower abdominal pain. On recovering from the anaesthetic, 38 patients complained of cramping lower abdominal pain that was sufficiently severe to warrant intramuscular analgesia (usually a single injection of papaveretum $15 \mathrm{mg}$ ). A further 24 patients required oral analgesia (usually pentazocine $50 \mathrm{mg}$ ). In all but one patient the pain had passed off completely within 24 hours. In this patient intermittent lower abdominal cramps continued for two weeks and required frequent use of oral analgesia. She has subsequently been seen for follow-up at one month and is now well. Abdominal and pelvic examination showed nothing abnormal throughout. All other patients were well after two weeks and each said she"was "back to normal." No other problems were identified.

\section{Comment}

We have found this technique of female sterilisation easy to learn and technically as simple as laparoscopic tubal diathermy. It seems to 
take less time. Tearing of the mesosalpinx is a recognised, if infrequent, complication and it can usually be controlled by reapplication of the ring. Postoperative lower abdominal pain has been a problem, and although only six of the patients at follow-up commented on its severity, it clearly caused them considerable distress in the immediate postoperative period. We now apply $2 \%$ lignocaine gel to the tubes at operation in an attempt to prevent this complication. The site of application of the ring on the tube seems to have no effect on the incidence or severity of the pain.

Advocates of this method of sterilisation claim advantages over tubal diathermy in terms of increased chance of reversibility. This claim has not yet been substantiated but might be understandable since there would appear to be less tubal damage than with diathermy. The pregnancy rate in the published series ${ }^{2-4}$ is extremely low, and although our follow-up is short (the study began in April 1976), no

Laparoscopic tubal diathermy is associated with an increased incidence of menstrual problems in patients seen up to 28 months after procedure. ${ }^{5}$ Long-term follow-up of patients sterilised using diathermy and a comparison with a similar series of patients sterilised using the Silastic-band technique is underway, and may provide data that is helpful in understanding this late complication of female sterilisation.

${ }^{1}$ Shepard, M K, Obstetrical and Gynaecological Survey, 1974, 29, 739.

2 Yoon, I B, Wheeler, C R, and King, R M, American fournal of Obstetrics and Gynecology, 1974, 120, 132.

${ }^{3}$ Brenner, W E, et al, Fertility and Sterility, 1976, 27, 256.

${ }^{4}$ Lee, W K, and Bageish, M S, British fournal of Obstetrics and Gynaecology, $1976,83,809$.

${ }^{5}$ Neil, J R, et al, Lancet, 1975, 2, 699.

(Accepted 20 fanuary 1977) EH3 9EW

A A TEMPLETON, MB, MRCOG, lecturer

M G KERR, FRCS, FRCOG, professor

Royal Infirmary, Edinburgh

R A COLE, $M B, M R C O G$, senior registrar

M M LEES, MD, MRCOG, consultant gynaecologist pregnancies have so far been reported.

\section{Department of Obstetrics and Gynaecology, University of Edinburgh}

The day after admission the blood sugar rose to $25 \mathrm{mmol} / 1$ ( $450 \mathrm{mg} / 100 \mathrm{ml})$, and soluble insulin (15-20 units daily) has been necessary to control his diabetes since then.

Serum samples were taken at one, 15, and 32 days and 14 months after admission, and were tested for antibody to infectious agents possibly associated with diabetes. Coxsackie group B virus antibody was titrated in a twohour neutralisation test at $37^{\circ} \mathrm{C}$. The reciprocals of antibody titres to Coxsackie B2 virus were $2560,2560,1280$, and 1280 , and Coxsackie B1, B3, B4, $\mathrm{B} 5$, and $\mathrm{B} 6$ antibody titres were $<10$. Titres of mumps, cytomegalovirus, complement-fixing antibody, and rubella haemagglutination-inhibiting antibody were all $<10$. Mycoplasma pneumoniae complement-fixing antibody titre was 20. For the titration of Coxsackie B immunoglobulin M (IgM) the indirect fluorescent antibody test was used with acetone-fixed monkey kidney cell monolayers infected with Coxsackie B1-6 viruses, patient's sera absorbed with Vero cells and heat aggregated human immunoglobulin, and sheep antihuman IgM conjugated with fluorescein isothiocyanate and absorbed with Vero cells. In the acute-phase sera the Coxsackie B2 IgM titre was 20, but staining of the other Coxsackie $B$ virus types also occurred. This test also showed a fibrillar anticellular IgM titre of 20 in the patient's acute-phase sera that could be removed by absorption with human myometrium. Coxsackie B2 IgM and the fibrillar anticellular $\operatorname{IgM}$ titres were both $<5$ in the serum taken 14 months after onset.

There were two siblings in the family. The brother aged 6 years was 4 years old when he developed diabetes in June 1973, but a sister aged 5 years and the father and mother were not diabetics. Serum samples were taken from the family six weeks after the patients' admission to hospital and they had antibody to most or all of the six Coxsackie B virus types. Coxsackie B2 antibody titres in the brother, sister, father, and mother were $640,>1280$, 160 , and 320 , respectively. The brother had rubella and cytomegalovirus antibody titres of $<10$; mumps and $M$ pneumoniae antibody titres were 20 The tissue type of the patient was HLA-A2, HLA-BW40, that of his brother was HLA-A2, HLA-BW40, HLA-B12, and that of his sister was HLA-A2, HLA-BW 40 .

\section{Comment}

The combination of lymphocytosis and high titres of Coxsackie B2 neutralising antibody and Coxsackie B IgM with acute diabetes in an 18-month-old child suggests that the diabetes was associated with a recent Coxsackie B2 virus infection. Coxsackie B IgM and fibrillar anticellular IgM were not detected 14 months after onset, which shows that the acute phase of the viral infection had ended. Coxsackie B virus neutralisation tests are type-specific, while Coxsackie B fluorescent antibody tests are not and are less sensitive. ${ }^{2}$ Fibrillar anticellular IgM autoantibody is found during the acute phase of other virus infections, ${ }^{3}$ and insulin release has been shown to be dependent on the integrity of the microtubular-microfilamentous system. ${ }^{4}$ Coxsackie B2 neutralising antibody was also present in the diabetic brother and in his sister, father, and mother, which shows that they were all infected with this virus at some time in the past. Cytomegalovirus, rubella, or mumps viruses and $M$ pneumoniae have also been implicated in juvenile-onset diabetes, but the patient and his brother had no evidence of recent infection with these agents. The tissue types of the patient and his brother were not those associated with juvenileonset diabetes.

We thank Mr D Middleton of the laboratories, Belfast City Hospital, for the tissue-typing report.

1 Cudworth, A G, British Fournal of Hospital Medicine, 1976, 16, 207.

2 MacWilliam, K M, and Cooper, M A, Fournal of Clinical Pathology, 1974, 27, 825.

${ }^{3}$ Samuel, M, Shirodaria, P V, and McMillan, S A, Clinical and Experimental Dermatology, 1976, 1, 269.

4 Van Obberghen, E, et al, Diabetes, 1975, 24, 892.

(Accepted 10 fanuary 1977)

\section{Patient, methods, and results}

An 18-month-old boy was admitted to hospital on 24 September 1975 with a one-week history of mild diarrhoea and polyuria. He was a welldeveloped, intelligent, active child and the only clinical abnormalities were fever $\left(37 \cdot 8^{\circ} \mathrm{C}\right)$, acetone on the breath, and glycosuria. Initial investigations showed: blood glucose $14.2 \mathrm{mmol} / 1(256 \mathrm{mg} / 100 \mathrm{ml})$, blood urea $8.3 \mathrm{mmol} / 1$ $(50 \mathrm{mg} / 100 \mathrm{ml})$, carbon dioxide total $19 \mathrm{mmol} / 1(8.5 \mathrm{ml} / \mathrm{dl})$; other electrolytes were normal. The total white cell count was $19.3 \times 10^{9} / 1\left(19300 / \mathrm{mm}^{3}\right)$ with $76 \%$ lymphocytes $\left(14.6 \times 10^{9} / 1 ; 14600 / \mathrm{mm}^{3}\right), 20 \%$ polymorphs $\left(3.9 \times 10^{9} / 1\right.$; $\left.3900 / \mathrm{mm}^{3}\right)$, and $4 \%$ monocytes $\left(0.8 \times 10^{9} / 1 ; 800 / \mathrm{mm}^{3}\right)$. A midstream urine specimen showed an increased pus cell count and coliforms were cultured.
Mid-Ulster Hospital, Magherafelt, Co Londonderry, N Ireland C WILSON, MRCP, consultant physician

Department of Microbiology and Immunobiology, Royal Victoria Hospital, Belfast, N Ireland

J H CONNOLLY, MD, FRCPI, consultant virologist

DOROTHY THOMSON, BSC, scientific officer 